\title{
Skrining Fitokimia Lima Jenis Tumbuhan Paku Polypodiaceae Dari Provinsi Riau
}

\section{Phytochemical Screening of Five Species of Polypodiaceae Ferns from Riau Province}

\author{
Wirdayanti ${ }^{1}$, Nery Sofiyanti ${ }^{*}$ \\ Jurusan Biologi FMIPA Universitas Riau, Pekanbaru, Riau, Indonesia \\ E-mail: nery.sofiyanti@lecturer.unri.ac.id *Penulis Korespondensi
}

\begin{abstract}
Many fern species from Polypodiaceae are used for traditional treatments. However, the phytochemical studies of these ferns from Riau Province are limited. This study aimed to investigate the phytochemical compounds (alkaloid, flavonoid, saponin, steroid, tannin, and terpenoid) of five species of Polypodiaceae ferns from Riau. Sampling had been carried out using the exploration method. Phytochemical screening was done at the Laboratory of Botany, Department of Biology, Faculty of Math and Natural Science, Universitas Riau. In this study, we use fresh rhizomes and leaves of five species of Polypodiaceae from Riau to prepare the aqueous extract. The phytochemichal screening on fern rhizomes showed the presence of four secondary metabolites such as alkaloid ( 5 species), flavonoid (1 species), tannin (1 species) and terpenoid ( 2 species). Saponin and stereoid were absent on fern rhizome. The leave extract showed a higher number of secondary metabolites, alkaloid (5 species), flavonoid ( 5 species), tanin (1 species), steroid (3 species) and terpenoid (1 species), while saponin was absent in leave extract of all of the Polypodiaceae species. Pyrrosia lanceolata showed the highest number of secondary metabolites (4 compounds).Keywords: leaf, fern, rhizome, phytochemical screening.
\end{abstract}

\begin{abstract}
Abstrak
Jenis-jenis paku dari famili Polypodiaceae banyak digunakan sebagai sumber obat tradisional. Namun kajian fitokimia jenis paku tersebut dari Provinsi Riau masih sangat terbatas. Penelitian ini bertujuan untuk mengetahui kandungan fitokimia yaitu alkaloid, flavonoid, saponin, steroid, tanin dan terpenoid dari lima jenis paku Polypodiaceae. Pengambilan sampel dilakukan dengan metode eksplorasi. Skrining fitokimia dilakukan di Laboratorium Botani, Jurusan Biologi, Fakultas Matematika dan Ilmu Pengetahuan Alam, Universitas Riau. Pada penelitian ini, organ yang digunakan untuk pembuatan ektrak cair adalah rimpang dan daun segar. Hasil skrining fitokimia pada rimpang paku yang diteliti menunjukkan kandungan emapat golongan metabolit sekunder yaitu alkaloid (5 jenis), flavonoid (1 jenis), tanin (1 jenis) dan terpenoid ( 2 jenis), sedangkan saponin dan stereoid tidak ditemukan pada ekstrak rimpang. Pada organ daun, senyawa metabolit sekunder lebih banyak dijumpai sebanyak 5 golongan senyawa yaitu alkaloid ( 5 jenis), flavonoid (5 jenis), tanin ( 1 jenis), steroid (3 jenis) dan terpenoid (1 jenis). Hanya golongan metabolit sekunder saponin yang tidak dijumpai pada ekstrak daun paku Polypodiaceae. Jenis yang paling banyak banyak menunjukkan kandungan metabolit sekunder adalah Pyrrosia lanceolata (4 senyawa).
\end{abstract}

Kata kunci: daun, paku, rimpang, skrining fitokimia

Diterima: 29 April 2019, disetujui: 28 Mei 2019

\section{Pendahuluan}

Famili Polypodiaceae merupakan salah satu famili tumbuhan paku dari Divisi Pteridophyta, yang terdiri dari sekitar 1.200 jenis dari 50 genus (Zhang et al. 2013). Pada umumnya jenis-jenis Polypodiaceae merupakan paku epifit atau epilitik, hanya sebagian saja yang terestrial, rimpang merayap pendek atau panjang dan ditutupi sisik, yang mendukung daun monomorfik dan dimorfik, dan pada umumnya berdaun tunggal atau majemuk, dengan sorus yang berada pada bagian abaksial (Zhang et al. 2013; Sofiyanti 
et al. 2015a). Jenis-jenis paku dari Famili Polypodiaceae telah banyak dilaporkan penggunaannya sebagai sumber obat tradisional di berbagai negara seperti, Pyrrosia untuk obat gatal, batuk (Ho et al. 2010), disentri (Arif et al. 2018); Microsorum sp. sebagai antiulcer (Ho et al. 2010); Drynaria quercifolia untuk menangani diare (Ahmed et al. 2015), asma, obat luka dan imflamasi (Cruz et al. 2017). Kajian ilmiah dari tumbuhan paku juga telah membuktikan potensinya sebagai sumber analgesik, antiimflamasi (Anuja et al. 2010), antioksidan (Das et al. 2014), dan antibakteri (Cruz et al. 2017).

Kajian tumbuhan paku dari di Provinsi Riau telah dilakukan oleh Sofiyanti (2013, 2019), Sofiyanti et al. (2013, 2015ab; 2017, 2019), Wulandari et al. (2016), Marpaung et al. (2016), Yusna et al. (2016), Sofiyanti dan Isda (2018, 2019). Sedangkan kajian khusus mengenai Paku Polypodiaceae di Riau telah dilaporkan oleh Sofiyanti \& Isda (2018), yang meneliti morfologi dan mikroforfologi sisik dan trikoma enam jenis paku. Namun kajian mengenai kandungan fitokimia tumbuhan paku dari kawasan ini masih sangat terbatas, dan baru dilaporkan oleh Yusna et al. (2016) yang meneliti kandungan fitokimia daun dari tujuh jenis Pteridaceae, sedangkan jenis-jenis lain dari kawasan ini belum pernah dilaporkan. Kajian fitokimia sangat penting dilakukan pada suatu tanaman yang digunakan sebagai sumber obat (Sangi et al. 2008). Hal ini bertujuan untuk mengetahui potensi tanaman tersebut agar dapat dikembangkan lebih lanjut sebagai sumber obat tradisional yang teruji

Tabel 1. Sampel 5 jenis paku dari famili Polypodiaceae

\begin{tabular}{ll}
\hline \multicolumn{1}{c}{ Nama Jenis } & \multicolumn{1}{c}{ Kode Spesimen } \\
\hline \hline 1. Pyrrosia angustata (Sw.) Ching & PA1, PA2 Panam, Wirda dan Nery 2018 \\
2. Pyrrosia lanceolata (L.) Farw. & PL1, Panam; PL2, Simpang TigaPekanbaru, \\
& Wirda dan Nery 2018 \\
3. Pyrrosia niphoboloides M.G. Price & PN1, PN2 Pekanbaru, Wirda dan Nery 2018 \\
4. Pyrrosia piloselloides (L.) M.G. Price & PP1, Bukit Raya; PP2 Pekanbaru, PP3 Simpang \\
& Tiga, Wirda dan Nery 2018 \\
5. Drynaria sparsisora (Desv.) T. Moore & DS1, Panam, Pekanbaru, Wirda dan Nery 2018 \\
\hline \hline
\end{tabular}

(Cruz et al. 2017). Berdasarkan survey pendahuluan yang telah dilakukan di berbagai daerah di Riau, jenis-jenis paku banyak yang dimanfaatkan sebagai sumber makanan, minuman herbal dan obat-obatan, termasuk juga jenis paku dari famili Polypodiaceae. Tujuan dari kajian ini adalah mengetahui kandungan fitokimia lima jenis Polypodiaceae dari Provinsi Riau.

\section{Metode Penelitian}

\section{Waktu dan tempat}

Penelitian ini dilakukan dari Juli Desember 2018. Pengambilan sampel dilakukan di 4 kawasan Kota Pekanbaru, Riau yaitu Perkebunan Sawit Simpang Tiga, Arboretum UNRI Panam, Bukit Raya dan Pekanbaru. Pembuatan herbarium, identifikasi dan uji fitokimia dilakukan di Laboratorium Botani Jurusan Biologi FMIPA Universitas Riau.

\section{Alat dan bahan \\ Peralatan yang digunakan pada penelitian ini kamera dan perlengkapan gelas, Sedangkan bahan yang digunakan adalah daun dan rimpang dari 5 jenis paku dari Famili Polypodiaceae (Tabel 1), aquades, kloroform, $\mathrm{H}_{2} \mathrm{SO}_{4}$ pekat, $\mathrm{HCl}$ pekat, amoniak-kloroform $0,05 \mathrm{~N}$ yaitu $1 \mathrm{ml}$ Amoniak pada $250 \mathrm{ml}$ kloroform, AAG, larutan Dragendrof, etanol $70 \%, \mathrm{H}_{2} \mathrm{SO}_{4} 2 \mathrm{~N}$, serbuk magnesium dan $\mathrm{FeCL}_{3} 1 \%$.}




\section{Pengambilan sampel dan pembuatan herbarium}

Spesimen diambil dari lapangan dengan metode ekplorasi berdasarkan Namau (1992), kemudian spesimen dibuat herbarium (Seshagirirao et al. 2016) untuk membantu proses identifikasi, kemudian spesimen didepositkan di Herbarium Riauensis. Referensi utama untuk identifikasi adalah Piggott (1998) dan Sofiyanti et al. (2015a).

\section{Skrining fitokimia}

Organ yang digunakan adalah organ daun dan rimpang paku yang masih segar (mengacu pada Cruz et al. 2017). Skrining fitokimia kualitatif dilakukan untuk mengetahui ada atau tidaknya kandungan metabolit sekunder dari golongan alkaloid, flavonoid, saponin, steroid, tanin, dan terpenoid pada paku yang diteliti berdasarkan Sangi et a.l (2008), Deepa et al. (2014) dan Raman et al. (2018). Analisis kualitatif dilakukan dengan mengamati perubahan warna yang terjadi. Khusus untuk saponin ditandai dengan terbentuknya buih yang stabil. Tabel 2 menunjukkan metode uji fitokimia dan parameter pengamatan yang mengindikasi adanya kandungan fitokimia. Apabila hasil uji menunjukkan ada kandungan senyawa maka diberi simbol $(+)$ dan apabila tidak ada diberi simbol (-) Hasil pengamatan didokumentasikan dan ditabulasikan. Kemudian data dianalisis secara deskriptif.

Tabel 2. Metode dan parameter hasil uji fitokimia

\begin{tabular}{|c|c|c|c|c|}
\hline No. & $\begin{array}{c}\text { Golongan } \\
\text { senyawa }\end{array}$ & Metode & Hasil uji & $\begin{array}{c}\text { Keterang } \\
\text { an }\end{array}$ \\
\hline$\overline{11}$ & Alkaloid & $\begin{array}{l}\text { gr sampel dihaluskan, + kloroform secukupnya }+10 \\
\text { ml amoniak-kloroform, disaring diambil filtrat, }+10 \\
\text { tetes H2SO4 2N, dikocok dan lapisan atas dipindah, }+ \\
3 \text { tetes Pereaksi Dragendorff. }\end{array}$ & $\begin{array}{l}\text { Warna merah, } \\
\text { jingga }\end{array}$ & Positif (+) \\
\hline 2 & Flavonoid & $\begin{array}{l}200 \text { gr sampel diiris halus, }+5 \mathrm{ml} \text { etanol } 70 \% \text {, } \\
\text { panaskan } 5 \text { menit }+3 \text { tetes HLC pekat }+0.2 \text { gr bubuk } \\
\text { magnesium. }\end{array}$ & $\begin{array}{l}\text { Warna kuning, } \\
\text { jingga sampai } \\
\text { merah tua atau } \\
\text { magenta }\end{array}$ & Positif (+) \\
\hline 3 & Saponin & $\begin{array}{l}2 \text { gr sampel diiris, rendam dengan akuades, didihkan } \\
\text { dan dikocok kuat }\end{array}$ & $\begin{array}{l}\text { Terbentuknya } \\
\text { buih / busa }\end{array}$ & Positif (+) \\
\hline 4 & Tanin & $\begin{array}{l}20 \mathrm{mg} \text { sampel diiris halus rendam dengan etanol } 70 \% \text {, } \\
1 \mathrm{ml} \text { larutan }+2 \text { tetes } \mathrm{FeCL}_{3} 1 \%\end{array}$ & $\begin{array}{l}\text { Warna hitam } \\
\text { kebiruan atau } \\
\text { hijau. }\end{array}$ & Positif (+) \\
\hline 5 & Steroid & $\begin{array}{l}50 \text { mg sampel dihaluskan }+ \text { AAG didiamkan } 15 \text { menit } \\
+3 \text { ettes } \mathrm{H}_{2} \mathrm{~S}_{4} \text { pekat }\end{array}$ & $\begin{array}{l}\text { Warna hijau, } \\
\text { biru }\end{array}$ & Positif (+) \\
\hline 6 & Terpenoid & $\begin{array}{l}50 \text { mg sampel dihaluskan }+ \text { AAG didiamkan } 15 \text { menit } \\
+3 \text { ettes } \mathrm{H}_{2} \mathrm{SO}_{4} \text { pekat }\end{array}$ & $\begin{array}{l}\text { Warna merah } \\
\text { jingga atau ungu }\end{array}$ & Positif (+) \\
\hline
\end{tabular}

(Sumber : Sangi et al. 2008; Deepa et al. 2014; Raman et al. 2018)

\section{Hasil dan Pembahasan}

Skrining fitokimia pada rimpang lima jenis tumbuhan paku dari Famili Polypodiaceae dari Riau dilakukan dengan analisis kualitatif berdasarkan perubahan yang terjadi setelah dilakukan uji setiap golongan. Gambar 1 menunjukkan hasil uji fitokimia pada rimpang. Pada Gambar 1 dapat diketahui bahwa semua ekstrak rimpang paku menunjukkan hasil positif alkaloid. Hal ini ditandai dengan terbentuknya warna merah pada semua ekstrak (Gambar 1a-e bagian alkaloid). Hasil uji flavonoid menunjukkan hanya satu jenis ekstrak dari Pyrrosia niphoboloides yang menunjukkan positif flavonoid, ditandai dengan munculnya warna kuning (Gambar 1d bagian flavonoid), sedangkan empat jenis lainnya tidak menunjukkan perubahan warna menjadi kuning. Untuk uji saponin semua ektrak rimpang tidak menghasilkan busa, sehingga hasil uji negatif. Sedangkan untuk uji tanin 
hanya satu jenis (Pyrrosia lanceolata) yang rimpangnya mengandung tanin, yang ditandai dengan munculnya warna kehijauan (Gambar 1c bagian tanin). Semua ekstrak rimpang paku pada penelitian ini menunjukkan hasil negatif terhadap steroid, sedangkan untuk terpenoid dijumpai pada ekstrak rimpang paku
Drynaria sparsisora dan Pyrrosia piloselloides karena menghasilkan warna jingga kemerahan (Gambar 1a dan 1e bagian steroid terpenoid). Tabulasi hasil skrining fitokimia rimpang paku disajikan pada Tabel 3.

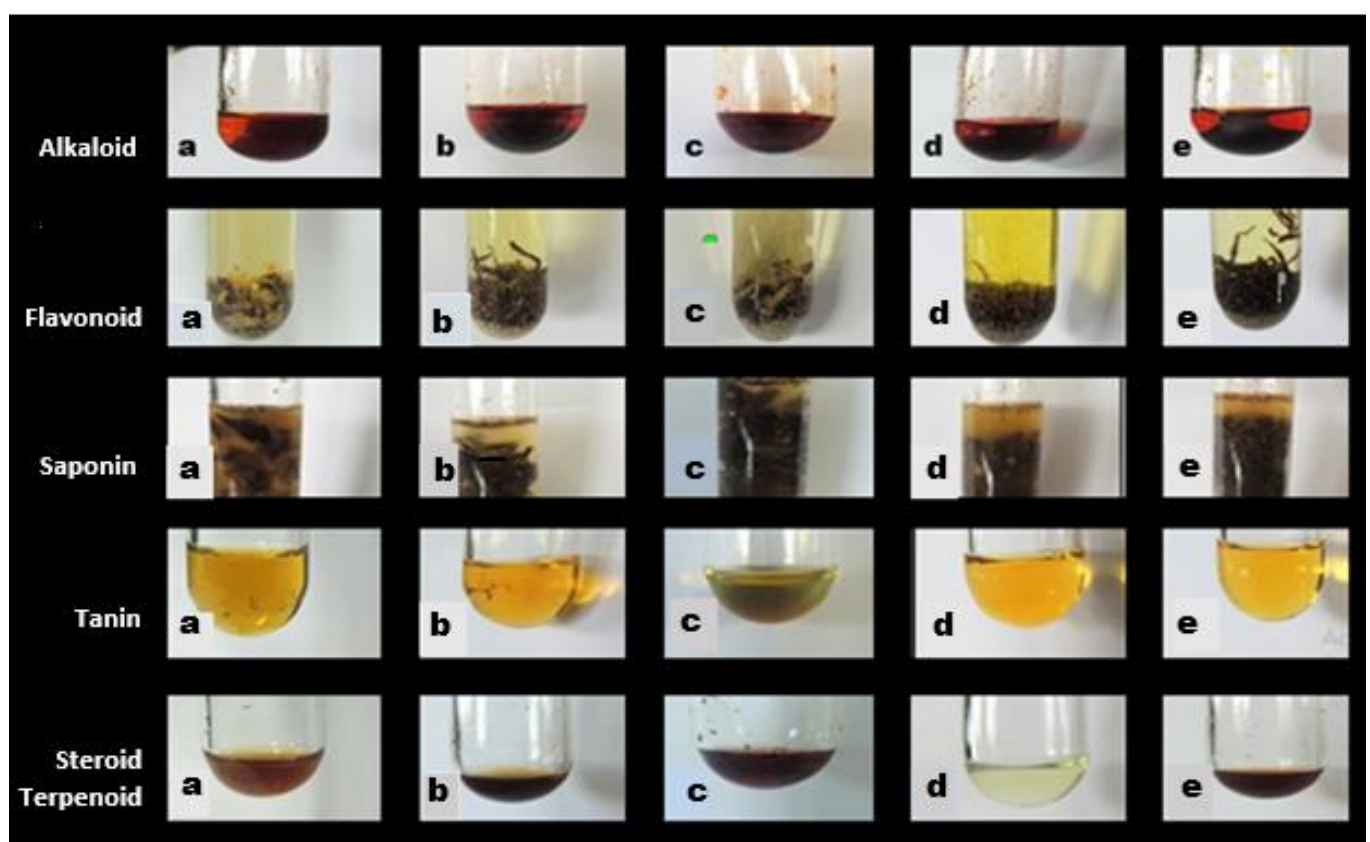

Gambar 1. Hasil uji fitokimia rhizoma tumbuhan paku. a. Drynaria sparsisora, b: Pyrrosia angustata, c: Pyrrosia lanceolata, d: Pyrrosia niphoboloides, e: Pyrrosia piloselloides.

Tabel 3. Hasil uji fitokimia rimpang 5 jenis tumbuhan paku dari famili Polypodiaceae

\begin{tabular}{clcccccc}
\hline \hline \multirow{2}{*}{ No } & \multicolumn{1}{c}{ Nama Jenis } & \multicolumn{5}{c}{ Hasil Skrining Fitokimia } \\
\cline { 3 - 7 } & & ALK & FLA & SAP & TAN & STE & TER \\
\hline \hline 1 & Drynaria sparsisora & + & - & - & - & - & + \\
2 & Pyrrosia angustata & + & - & - & - & - & - \\
3 & Pyrrosia lanceolata & + & - & - & + & - & - \\
4 & Pyrrosia niphoboloides & + & + & - & - & - & - \\
5 & Pyrrosia piloselloides & + & - & - & - & - & + \\
\hline
\end{tabular}

Keterangan: $\quad$ ALK = Alkaloid, FLA = Flavonoid, SAP = Saponin, TAN = Tanin, STE = Steroid, TER $=$ Terpenoid, - = tidak mengandung senyawa metabolit sekunder (negatif), $+=$ mengandung senyawa metabolit sekunder (positif)

Hasil uji fitokimia daun paku yang diteliti disajikan pada Gambar 2. Hasil uji alkaloid pada daun menunjukkan hasil yang sama dengan rimpang, yaitu positif alkaloid pada semua ekstrak jenis paku ditandai dengan munculnya warna merah. Kandungan flavonoid juga dijumpai pada semua ekstrak daun paku Polypodiaceae, yang ditandai dengan terbentuknya warna kuning. Hasil uji senyawa saponin dan tanin pada daun, sama dengan hasil uji pada rimpang. Pada kajian ini semua ekstrak daun menunjukkan hasil negatif saponin karena tidak terbentuk buih / busa. Untuk uji tanin, hanya jenis Pyrrosia 
lanceolata yang menunjukkan adanya kandungan tanin yang ditandai dengan munculnya warna hijau. Uji steroid menunjukkan tiga jenis paku yang diteliti mengandung steroid, yaitu Drynaria sparsisora, Pyrrosia angustata dan Pyrrosia piloselloides. Ekstrak daun ketiga jenis paku ini menghasilkan warna hijau. Sedangkan jenis paku menunjukkan adanya kandungan terpenoid hanya jenis Pyrrosia lanceolata, ditandai dengan munculnya warna jingga atau merah. Tabulasi hasil uji fitokimia pada daun paku Polypodiaceae disajikan pada Tabel 4 berikut ini.

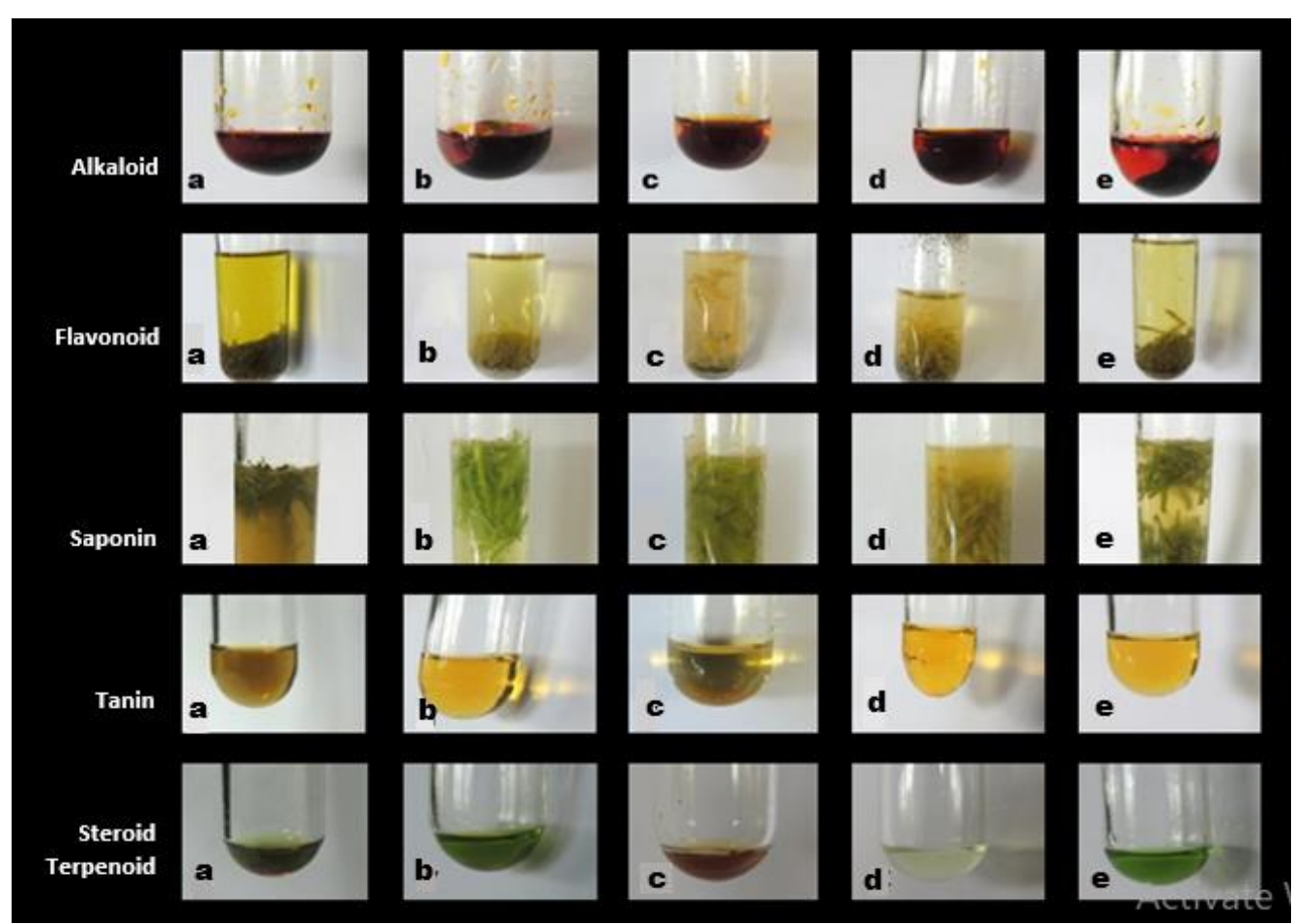

Gambar 2. Hasil uji fitokimia daun tumbuhan paku. a. Drynaria spassisora, b: Pyrrosia angustata, c: Pyrrosia lanceolata, d: Pyrrosia niphoboloides, e: Pyrrosia piloselloides.

Tabel 4. Hasil uji fitokimia daun 5 jenis tumbuhan paku dari famili Polypodiaceae

\begin{tabular}{clcccccc}
\hline \multirow{2}{*}{ No } & \multirow{2}{*}{ Nama Jenis } & \multicolumn{6}{c}{ Hasil Skrining Fitokimia } \\
\cline { 3 - 7 } & & ALK & FLA & SAP & TAN & STE & TER \\
\hline 1 & Drynaria sparsisora & + & + & - & - & + & - \\
\hline 2 & Pyrrosia angustata & + & + & - & - & + & - \\
\hline 3 & Pyrrosia lanceolata & + & + & - & + & - & + \\
\hline 4 & Pyrrosia niphoboloides & + & + & - & - & - & - \\
\hline 5 & Pyrrosia piloselloides & + & + & - & - & + & - \\
\hline
\end{tabular}

Keterangan: $\quad$ ALK = Alkaloid, FLA = Flavonoid, SAP = Saponin, TAN = Tanin, STE = Steroid, TER = Terpenoid, - = tidak mengandung senyawa metabolit sekunder (negatif), $+=$ mengandung senyawa metabolit sekunder (positif).

Pada penelitian ini telah diuji kandungan fitokimia enam senyawa metabolit sekunder dari organ rimpang dan daun dari lima jenis paku Polypodiaceae di Riau. Hasil penelitian menunjukkan bahwa ekstrak rimpang dan daun semua jenis paku yang diuji memberikan hasil yang sama pada uji tiga senyawa, alkaloid (positif), saponin (negatif) dan tanin (hanya positif pada jenis Pyrrosia lanceolata). Sedangkan tiga senyawa lainnya 
(flavonoid, steroid dan terpenoid) memberikan hasil yang berbeda pada rimpang dan daun.

Alkaloid merupakan golongan metabolit sekunder dijumpai pada sebagian besar golongan tumbuhan (Matsuura \& Fett-Neto 2015). Alkaloid merupakan golongan senyawa organik, yang mempunyai komponen dasar nitrogen basa (Sangi et al. 2008). Pada tumbuhan, senyawa ini berperan dalam pertahanan tanaman terhadap herbivora dan serangan pathogen karena toksisitasnya (Deepa et al. 2014; Matsuura \& Fett-Neto 2015). Pada penelitian ini, hasil uji golongan alkaloid menunjukkan bahwa pada rimpang dan daun semua jenis paku Polypodiaceae mengandung alkaloid. Hal ini ditandai dengan munculnya warna merah jingga. Pada penggunaan pereaksi Dragendroff, perubahan warna tersebut dikarenakan reaksi potassium bismuth iodide (Kumar 2014). Hasil penelitian ini mendukung kajian Korwar et al. (2010) dan Deepa et al. 2014), yang mengidentifikasi adanya kandungan senyawa alkaloid pada paku Polypodiaceae seperti Drynaria quercifolia (Korwar et al. 2010) dan Pyrrosia lanceolata (Deepa et al. 2014). Namun hasil kajian fitokimia menggunakan pelarut metanol yang dilakukan oleh Arif et al. (2018) tidak menemukan adanya alkaloid pada Pyrossia piloselloides. Hal ini berbeda dengan hasil yang diperoleh pada kajian ini. Perbedaan hasil uji ftokimia pada jenis yang sama, disebabkan oleh penggunaan pelarut yang berbeda seperti yang dilaporkan oleh Korwar et al. (2010), Hossain et al. (2013) dan Raman et al. (2018).

Senyawa flavonoid merupakan senyawa bioaktif dari golongan fenol yang banyak dijumpai pada tumbuhan (Panche et al. 2016). Adanya kandungan flavonoid pada penelitian ini ditandai dengan munculnya warna kuning, jingga merah tua sampai magenta (Sangi et al. 2008; Deepa et al. 2014). Perubahan warna ini terjadi karena terjadinya reduksi magnesium dan $\mathrm{HCl}$ pekat (Robinson 1995). Pada tumbuhan, flavonoid memegang peranan penting pada transport hormon auxin, perkembangan akar dan batang dan polinasi (Weston \& Mathesius 2013). Selain itu juga mempunyai aktifitas sebagai antibakteri (Xie et al. 2015), antijamur, antivirus (Weston \&
Mathesius 2013), antiimfamasi dan antikanker (Panche et al. 2016). Pada penelitian ini, uji flavonoid menunjukkan hasil yang berbeda pada ekstrak rimpang dan daun. Senyawa ini hanya dijumpai pada rimpang paku Pyrrosia nipoboloides, sedangkan pada organ daun, kandungan flavonoid dijumpai pada semua jenis paku yang diteliti, yang ditandai dengan munculnya warna kuning atau jingga. Paku Drynaria sparsisora menunjukkan intensitas warna kuning jingga yang lebih pekat dibandingkan jenis paku lain, hal ini mengindikasikan kandungan flavonoid yang dijumpai lebih tinggi. Kandungan flavonoid pada paku Polypodiaceae lainnya, telah dilaporkan oleh pada jenis Drynaria fortunei (Wong et al. 2013), sehingga jenis ini dimanfaatkan secara tradisional bagi penyakit tulang (Pang et al. 2012).

Saponin berasal dari bahasa Latin yaitu sapo (sabun), karena mempunyai senyawa aktif permukaan yang bersifat seperti sabun (Faizal \& Geelen 2013) yaitu pada saat diguncang akan menghasilkan buih / busa karena terbentuknya larutan koloidal dalam air. Secara kimia, saponin merupakan senyawa glikosida yang banyak dijumpai pada golongan tumbuhan (Guclu-Ustundag \& Maaza 2007; Faizal \& Geelen 2013). Saponin bermanfaat sebagai peptisida, insektisida, moluskasida, fungisida dan penggunaan pada industri untuk foaming (Faizal \& Geelen 2013). Pada penelitian ini, hasil uji saponin pada organ rimpang dan daun paku yang diteliti, menunjukkan semua jenis paku tidak ditemukan adanya saponin, karena pada saat uji tidak terbentuk buih pada permukaan atas. Hasil negatif saponin juga dilaporkan pada jenis paku lain seperti Lygodium flexuosum dan Ampelopteris prolifera oleh Barthi (2018), yang menggunakan pelarut benzena dan petrolium eter. Kajian fitokimia pada tiga jenis paku Polypodiaceae yang dilakukan oleh Cruz et al. (2017) menggunakan ekstrak metanol menunjukkan hasil positif saponin, namun jenis yang digunakan berbeda dengan kajian ini.

Hasil uji senyawa tanin pada penelitian ini menunjukkan hanya satu jenis paku yang positif tanin yaitu Pyrrosia lanceolata, baik pada rimpang maupun daun. Tanin merupakan 
astringent yaitu polifenol pada tumbuhan yang menghasilkan rasa pahit (Ashok \& Uphadyaya 2012). Tanin mempunyai kemampuan mengikat protein dan makromolekul sehingga banyak dimanfaatkan pada proses taning (Constabel et al. 2014) dan juga digunakan sebagai pewarna tekstil, kulit, makanan, kosmetik dan kertas (Hong 2018). Hasil uji positif tanin akan menunjukkan warna hijau atau kebiruan seperti terlihat pada hasil uji rimpang dan daun Pyrrosia lanceolata. Warna tersebut muncul karena adanya reaksi garam besi (Li et al. 2016). Pada kajian kandungan fitokimia golongan tanin paku Polypodiaceae yang telah dilakukan sebelumnya pada jenis Drynaria quercifolia menunjukkan bahwa pada pelarut yang berbeda menghasilkan hasil uji tanin yang berbeda (Ramesh et al. 2002) karena setiap pelarut mempunyai tingkat kepolaran yang berbeda (Suryani et al. 2019). Pada kajian tersebut, tanin tidak ditemukan pada penggunaan pelarut hexana dan $\mathrm{CHCl}$, sedangkan pada pelarut metanol menunjukkan positif tanin. Namun kajian Deepa et al. (2014) pada paku Polypodiaceae genus Pyrrosia, menunjukkan hasil yang konsisten pada enam pelarut, yaitu negatif tanin. Kandungan tanin pada tumbuhan paku juga pernah dilaporkan oleh Ghorpade et al. (2019) pada empat jenis paku dari genus Cheilanthes. Pelarut yang digunakan pada penelitian tersebut adalah metanol. Menurut Ahmed et al. (2016) jenis yang sama tetapi tumbuh pada habitat yang berbeda dapat menunjukkan hasil uji fitokimia yang berbeda, karena adanya pengaruh lingkungan.

Pengujian steroid dan terpenoid dilakukan bersamaan dengan penambahan pereaksi Lierman Bauchard yang mengandung $\mathrm{H}_{2} \mathrm{SO}_{4}$ dan asam asetat anhidrat (Malik \& Ahmad 2017). Perubahan warna yang terjadi akan menunjukkan adanya kandungan steroid (hijau, biru) atau terpenoid (merah, jingga sampai ungu) (Sangi et al. 2008; Deepa et al. 2014; Raman et al. 2018). Steroid merupakan salah satu senyawa metabolit sekunder golongan terpenoid yang banyak dijumpai pada tanaman. Fungsi dari steroid antara lain meningkatkan hormon pertumbuhan dan perlindungan tanaman dari serangan insekta (Patel \& Savjani 2015). Pada kajian ini, steroid tidak dijumpai pada semua ektrak rimpang paku yang diuji, sedangkan pada ekstrak daun ada tiga jenis paku positif steroid yaitu Drynaria sparsisora, Pyrrosia angustata dan Pyrrosia piloselloides. Ekstrak daun ketiga jenis paku ini menghasilkan warna hijau. Warna ini terbentuk karena adanya reaksi dari $\mathrm{H}_{2} \mathrm{SO}_{4}$ dan asam asetat anhidrat (Malik \& Ahmad 2017). Tanaman yang menghasilkan steroid berpotensi sebagai agen antiinflamasi (Pattel \& Sajani 2015). Untuk uji terpenoid ditemukan pada rimpang dua jenis paku, yaitu Drynaria sparsisora dan Pyrossia piloselloides, sedangkan pada daun hanya ditemukan pada jenis paku Pyrrosia lanceolata, ditandai dengan munculnya warna jingga atau merah. Tanaman yang mempunyai kandungan terpenoid berpotensi sebagai sumber antimikroba, antioksidan, anti kanker dan pelindung syaraf (Malik \& Ahmad 2017).

Hasil penelitian ini menunjukkan adanya persamaan hasil uji senyawa alkaloid, saponin dan tanin pada rimpang dan daun dari lima jenis paku Polypodiaceae. Sedangkan pada tiga senyawa lainnya yaitu flavonoid, steroid dan terpenoid menunjukkan hasil yang berbeda. Perbedaan kandungan fitokimia yang pada rimpang dan daun paku pernah dilaporkan oleh Cruz et al. (2017) pada tiga paku polypodiaceae yaitu Drynaria quercifolia (L.) J. Sm.,, Microsorum punctatum (L.) Copel dan Pyrrosia adnascens (Sw.) Ching. Pada penelitian ini hanya menggunakan ekstrak cair, oleh arena itu perlu dilakukan penelitian lebih lanjut menggunakan ekstrak yang berbeda, karena berdasarkan kajian Ramesh et al. (2002), Raman et al. 2018 dan Cruz et al. (2017) penggunaan ekstrak yang berbeda dapat menghasilkan hasil uji fitokimia yang berbeda.

\section{Simpulan dan Saran}

Senyawa metabolit sekunder yang ditemukan pada lima jenis paku Polypodiaceae pada penelitian ini adalah alkaloid, flavonoid, tanin, steroid dan terpenoid yang lebih banyak ditemukan pada daun dibandingkan rimpang. Jenis Pyrrosia lanceolata menunjukkan hasil positif senyawa metabolit sekunder terbanyak 
(4 senyawa) dibandingkan jenis lain. Pada penelitian ini hanya menggunakan satu pelarut yaitu air, sehingga perlu dilakukan kajian lanjut menggunakan pelarut yang berbeda.

\section{Ucapan Terima Kasih}

Penelitian ini didanai oleh DRPM KEMENRISTEK DIKTI atas nama penulis korespondensi.

\section{Daftar Pustaka}

Ahmed, F.A., Rahman, A. \& Mubassara, S. 2016. Phytochemical composition, antioxidant activity and cytotoxicity of Blumea lacera Linn. from two different habitats. Jahangirnagar University Journal of Biological Sciences. 3. 37. 10.3329/jujbs.v3i1.28276.

Ahmed, M.N., Matt, G., Kabidul, A.M.N., Mannan, M. \& Rahman, M. 2015. Clinical Appraisals And Phytochemical Potential Of Ethnomedicinal Pteridophyte: Drynaria quercifolia (L.) J. Smith (Polypodiaceae). Pharmacologyonline. 1. 4-17.

Anuja, I., Latha, P.G., Suja, S., Sukumaran, S., Shine, V.J ., Sini, S., Pradeep, S., Periya, S. \& Rajasekharan, S. 2010. Anti-inflammatory and analgesic properties of Drynaria quercifolia (L.) J. Smith. Journal of Ethnopharmacology. 132. 456-460. 10.1016/j.jep.2010.08.038.

Arif, M.Z., Zainuddin, N.A.S.N, Zakaria, I.S., , Wahab, W.N.A.W.A, \& Sul'ain, M.D.. 2018. Phytochemical Screening and Toxicological Evaluation of Pyrrosia piloselloides Extracts. International Medical Journal, 25 ( 3): 177 180.

Ashok, P.K. \& Upadhyaya, K. 2012. Tannins are Astringent. C Journal 1(3): 45-50.

Barthi, M. 2018. Studies on phytochemical analysis and screening for active compounds in some ferns of Ranchi and Latehar district. International Journal of Academic Research and Development, 3(1): 33-44.

Constabel, P.C., Yoshida, K. \& Walker, V. 2014. Diverse Ecological Roles of Plant Tannins: Plant Defense and Beyond. In Recent Advances in Polyphenol Research, Volume 4, First Edition. John Wiley \& Sons. 10.1002/9781118329634.ch5.

Cruz, R.Y.D., Ang, A.M.G., Doblas, G.Z., Librando, I.L., Porquis, H.C., Batoctoy, B.C.L.S., Cabresos, C.C., Jacalan, D.R.Y., \& Amoroso, V.B. 2017. Phytochemical Screening, Antioxidant and Anti-inflammatory Activities of the Three Fern (Polypodiaceae) Species in Bukidnon, Philippines. Bulletin of Environment, Pharmacology and Life Sciences 6(3) : 28-33.

Das, B. Duttachoudhury, M., Dey, A., \& Das T., Anupam N., \& Deb, Lo. 2014. Antioxidant and anti-inflammatory activity of aqueous and methanolic extracts of rhizome part of Drynaria quercifolia (L.) J. Smith. International Journal of Pharmacy and Pharmaceutical Sciences. 6. 43-49.

Faizal, A. \& Geelen, D. 2013. Saponins and their role in biological processes in plants. Phytochem Rev., 12: 877-893. DOI 10.1007/s11101-013-9322-

Ghorpade, P.N., Thakar, S., Dongare, M \& Kale, M. 2019. Phytochemical Analysis Of Four Cheilanthes Species From Northern Western Ghats Of India. Research Journal of Pharmaceutical, Biological and Chemical Sciences. 1. 92-100. 10.26479/2015.0102.04.

Guclu-Ustundag, O. \& Mazza, G. 2007. Saponins: Properties, Applications and Processing. Critical Reviews in Food Science and Nutrition. 47. 23158. 10.1080/10408390600698197.

Hong, K. 2018. Effects of tannin mordanting on coloring and functionalities of wool fabrics dyed with spent coffee grounds. Fashion and Textiles 5: 2 11. 10.1186/s40691-018-0151-3.

Hossain, M.A., Al-Raqmi, K.A.S., Al-Mijizy, Z.H., Weli, A.M., \& Al-Riyami, Q. 2013. Study of total phenol, flavonoids contents and phytochemical screening of various leaves crude extracts of locally grown Thymus vulgaris. Asian Pac J Trop Biomed, 3(9): 705-710. doi: 10.1016/S2221-1691(13)60142-2.

Ho R., Teai T., Bianchini JP., Lafont R., \& Raharivelomanana P. 2010. Ferns: From Traditional Uses to Pharmaceutical Development, Chemical Identification of Active Principles. In: Kumar A., Fernández H., Revilla M. (eds) Working with Ferns. Springer, New York, NY

Korwar, P.G., Beknal, A.K., Patil, B.S., Halkai, M.A., Kurkani, U., Hariprasanna, R.C., \& Soodam, S.R. 2010. A Study On Phytochemical Investigation Of Drynaria Quercifolia Linn Rhizome. Pharmaceutical Sciences And Research, 1(12) 148 - 158.

Kumar, S. 2014. Alkaloidal Drugs - A Review. Asian Journal of Pharmaceutical Science \& Technology, 4(3): 107-119. 107.

Li, Y.M., Miao, X., Wela, Z.G., Cula, J., LI, S.Y., Hana, R.M. Zhang, Y., \& Wela, W. 2016. Iron-Tannic Acid Nanocomplexes: Facile Synthesis And Application For Removal Of Methylene Blue From Aqueous Solution. Digest Journal of 
Nanomaterials and Biostructures 11(4): 10451061.

Malik, SK. \& Ahmad, MKF. 2017. Qualtitative And Quantitative Estimation Of Terpenoid Contents In Some Important Plants Of Punjab, Pakistan. Pakistan Journal of Science 69(2): 150 - 154.

Marpaung AA, Sofiyanti N, Iriani D, \& Fitmawati. 2016. Morfologi spora paku Pteridaceae di Hutan PT. CPI Rumbai Riau. Jurnal Riau Biologia 1(2): 148-154.

Matsuura, H. \& Fett-Neto, A. 2015. Plant Alkaloids: Main Features, Toxicity, and Mechanisms of Action. 10.1007/978-94-007-6728-7 2-1.

Namau HN. 1992. Germplasm Exploration and Collection. Dinteria 23: 50-54.

Panche, A. N., Diwan, A.D., \& Chandra, S.R. 2016. Flavonoid: an overview. J Nutr Sci. 5: e47. doi: $10.1017 /$ jns.2016.41.

Pang, W., Wang, X., Wong, K., Leung, P., Yao, X., \& Wong, W. 2012. Total Flavonoid Fraction of Rhizoma Drynaria Improves Bone Properties in Ovariectomized Mice and Exerts Estrogen-Like Activities in Rat Osteoblast-Like (UMR-106) Cells. Journal of Food and Drug Analysis, 20, Suppl.: 265-269.

Patel, SS. \& Savjani, J.K. 2015. Systematic review of plant steroids as potential antiinflammatory agents: Current status and future perspectives. The Journal of Phytopharmacology, 4(2): 121125

Piggott, A.G. 1998. Fern of Malaysia in Color. Tropical Press Sdn.Bhd.,Malaysia.

Journal of Plant Taxonomy, 22(2): 137-14.DOI http://dx.doi.org/10.3329/bjpt.v22i2.26075.

Sofiyanti N, Iriani D, Fitmawati, \& Marpaung, A.A 2017. A Note on the Fern (Pteridophyte) Diversity from Riau. Applied Science and Technology, 1(1):478 - 481 .

Sofiyanti, N. \& Isda, MN. 2018. Kajian Morfologi dan Mikromorfologi (Sisik serta Trikoma) 4 Jenis Pyrrosia Mirb. (Polypodiaceae) Di Provinsi Riau. JurnalBologiTropis, 18 (2): 174 - 181 DOI: http://dx.doi.org/10.29303/jbt.v18i2.857

Sofiyanti, N., Iriani, D., Fitmawati \& Marpaung, A.A 2019. Morphology, palynology, and stipe anatomy of four common ferns from Pekanbaru, Riau Province, Indonesia. Biodiversitas, 20(1): 327 - 336. DOI: 10.13057/biodiv/d200138

Sofiyanti, N. 2019. Keanekaragaman Jenis Flora Epifit Di Hutan Kota Pekanbaru, Provinsi Riau dan Kajian Kekerabatannya. Jurnal Biologi Universitas Andalas, 7(1) - Maret 2019: 34-42.

Suryani, N.C., Permana, D.G.M. \& Jambe, A.A.G.N.A. 2019. Pengaruh Jenis Pelarut Terhadap
Raman, V., Rana, A. \& Sarma, A. 2018.. Phytochemical Analysis \& Anthelmintic Activity Of Leaves Of Leucaena Leucocephala. World Journal of Pharmaceutical Research, 7: 822-833. 10.20959/wjpr201811-12411.

Ramesh, N., Viswanathan, M., Saraswathy, A., Balakrishna, K., Brindha, P. \& Lakshmanaperumalsamy, P. 2002. Phytochemical and antimicrobial studies on Drynaria quercifolia. Fitoterapia, 72. 934-6. 10.1016/S0367-326X(01)00342-2.

Robinson, T. 1995. Kandungan Organik Tumbuhan Tinggi. Penerbit ITB.

Deepa, G.M., Ruby, R. \& Sara, C. 2014. Preliminary phytochemichal Analysis of Pyrrosia lanceolata (L.) Farwell. International Research Journal of Pharmacy, 5(12): 879-883.

Sangi M, Runtuwene M.R.J, Simbala H.E.I dan Makang V.M.A. 2008. Analisis Fitokimia Tumbuhan Obat Di Kabupaten Minahasa Utara. Chem. Prog $1(1): 47-53$.

Seshagirirao, K., Hari, K., Kusuma, V., Badithi, N., Kizukala, J.\& Basimalla, KR.,Rutuparna, J. \& Dhokne, KB. 2016. Preparation Of Herbarium Specimen For Plant Identification And Voucher Number. Roxburghia. 6. 111-119.

Sofiyanti N, D. Iriani, \& A.A. Roza. 2015a. Morfologi tumbuhan Paku di Taman Hutan Raya Sultan Syarif Hasyim, Riau. Unri Press, Pekanbaru.

Sofiyanti N, Iriani D, Fitmawati, \& Roza AA. 2015 b. Stenochlaena riauensis (Blechnaceae), A new fern species from Riau, Indonesia. Bangladesh

Kandungan Total Flavonoid Dan Aktivitas Antioksidan Ekstrak Daun Matoa (Pometia Pinnata) (20 Juli 2019). file:///C:/Users/User/Downloads/22645-1-441901-10-20160727.pdf

Weston, A.L. \& Mathesius, U. 2013. Flavonoids: Their Structure, Biosynthesis and Role in the Rhizosphere, Including Allelopathy. Journal of Chemical Ecology. 39. 10.1007/s10886-0130248-5.

Wong, K., Pang, W., Wang, X., Mok, S., Lai, W, Chow, D., Leung, P., Yao, X. \& Wong, Ma. 2013. Drynaria fortunei-derived total flavonoid fraction and isolated compounds exert oestrogenlike protective effects in bone. The British journal of nutrition. 110. 1-11. 10.1017/S0007114512005405.

Wulandari D., Sofiyanti, N. , \&Fitmawati. 2016. Keanekaragaman Jenis Polypodiaceae Di Hutan PT. CPI Rumbai Provinsi Riau Berdasarkan Karakter Morfologi. Jurnal Riau Biologia, 1(2): 135-139. 
Xie, Y., Yang, W., Tang, F. \& Ren, L. 2015 Antibacterial activities of flavonoids: structureactivity relationship and mechanism. Curr. Med. Chem. 2015;22(1):132-49.

Yusna, M., Sofiyanti, N. \& Fitmawati. 2016. Keanekaragaman Pteridaceae Berdasarkan Karakter Morfologi dan Fitokimia di Hutan PT. Chevron Pacific Indonesia (PT. CPI) Rumbai. Jurnal Riau Biologia, 1(2): 165-172.
Zhang, X. C., S. G. Lu, Y. X. Lin, X. P. Qi, S. Moore, F. W. Xing, F. G. Wang, P. H. Hovenkamp, M. G. Gilbert, H. P. Nooteboom, B. S. Parris, C. Haufler, M. Kato \& A. R. Smith. 2013. Polypodiaceae. Pp. $758-850$ in Z. Y. Wu, P. H. Raven \& D. Y. Hong, eds., Flora of China, 2-3 (Pteridophytes). Beijing: Science Press; St. Louis: Missouri Botanical Garden Press. 